Supplement of Biogeosciences, 12, 2773-2790, 2015

http://www.biogeosciences.net/12/2773/2015/

doi:10.5194/bg-12-2773-2015-supplement

(C) Author(s) 2015. CC Attribution 3.0 License.

(c) (1)

Supplement of

\title{
The dynamic of the annual carbon allocation to wood in European tree species is consistent with a combined source-sink limitation of growth: implications for modelling
}

\section{J. Guillemot et al.}

Correspondence to: J. Guillemot (joannes.guillemot@gmail.com)

The copyright of individual parts of the supplement might differ from the CC-BY 3.0 licence. 


\section{Supplement}

Supplement S1. Site description

Supplement S2. Reconstruction of the historical circumference trajectories

Supplement S3. Calculation of the woody biomass

Supplement S4. Annual woody biomass increment features

Supplement S5. Classes of soil nutrient availability

Supplement S6. Species-specific aggregation periods of $C$ fluxes used in the analyses

Supplement S7. Physiology-based index of stress water intensity

Supplement S8. Modelling of the biomass growth onset

Supplement S9. Uncertainty of the CASTANEA simulations of carbon fluxes

Supplement S10. Seasonal agreement between AWBIs and the components of the forest carbon balance 


\section{Supplement 1. Site description}

A complete description of the 49 sites used in the study is available in Table S1.1.

Table S1.1 (next two pages). Description of the studied sites.

ID letters indicate species (F: Fagus sylvatica; Qr: Quercus robur, Qp : Quercus petraea, P: Picea abies, Qi : Quercus ilex). Lat.: Latitude, Long. : Longitude, Elev. Elevation, Exp.: Exposure, LNC: leaf nitrogen content $\left(\mathrm{gN} \mathrm{gDM}^{-1}\right)$, SWHC: soil water holding capacity, $\mathrm{H}$ : dominant height in 1994, LAl: leaf area index (unitless), ETP: potential evapotranspiration (calculated using the Penman-Monteith equation on a daily basis), Prec.: precipitation, T: temperature, SNA: soil nutrient availability classes (1=high, $2=$ medium, $3=$ low nutrient availability), period: dates and number of available AWBI measurements. ETP, Prec. and T are averaged annual values. 


\begin{tabular}{|c|c|c|c|c|c|c|c|c|c|c|c|c|c|c|c|}
\hline ID & $\begin{array}{l}\text { Lat. } \\
(\mathrm{N})\end{array}$ & $\begin{array}{l}\text { Long. } \\
\text { (E/W) }\end{array}$ & $\begin{array}{c}\text { Elev. } \\
(\mathrm{m})\end{array}$ & $\begin{array}{c}\text { Slope } \\
\%\end{array}$ & Exp. & LNC & $\begin{array}{c}\text { Age } \\
\text { (year) }\end{array}$ & $\begin{array}{c}\text { SWHC } \\
(\mathrm{mm})\end{array}$ & $\begin{array}{c}\mathrm{H} \\
(\mathrm{m})\end{array}$ & LAI & $\begin{array}{l}\text { ETP } \\
(\mathrm{mm})\end{array}$ & $\begin{array}{l}\text { Prec. } \\
(\mathrm{mm})\end{array}$ & $\mathrm{T}\left({ }^{\circ} \mathrm{C}\right)$ & SNA & $\begin{array}{c}\text { period } \\
\text { (nb. of years) }\end{array}$ \\
\hline$F 03$ & $46^{\circ} 11^{\prime}$ & $2^{\circ} 59^{\prime} \mathrm{E}$ & 590 & 15 & $\mathrm{~N}$ & 28.3 & 87 & 155 & 29 & 6.6 & 1079 & 778 & 10.5 & 2 & $1994-1970(25)$ \\
\hline F 04 & $44^{\circ} 07^{\prime}$ & $5^{\circ} 47^{\prime} \mathrm{E}$ & 1300 & 50 & $\mathrm{~N}$ & 26.7 & 85 & 180 & 25.5 & 6.6 & 1328 & 917 & 11.6 & 1 & 1994-1983 (12) \\
\hline$F 09$ & $42^{\circ} 55^{\prime}$ & $1^{\circ} 16^{\prime} \mathrm{E}$ & 1250 & 32 & SW & 26.3 & 152 & 110 & 21.8 & 4.6 & 1069 & 1068 & 11.5 & 3 & 1994-1964 (31) \\
\hline$F 14$ & $49^{\circ} 10^{\prime}$ & $0^{\circ} 51^{\prime} \mathrm{W}$ & 90 & 0 & - & 25.3 & 83 & 83 & 25.7 & 6.2 & 859 & 892 & 10.8 & 3 & 1994-1976 (19) \\
\hline$F 21$ & $47^{\circ} 48^{\prime}$ & $4^{\circ} 51^{\prime} \mathrm{E}$ & 400 & 3 & NE & 23.5 & 128 & 80 & 28.6 & 4.3 & 966 & 934 & 9.7 & 1 & $1994-1975$ (20) \\
\hline$F 26$ & $44^{\circ} 55^{\prime}$ & $5^{\circ} 17^{\prime} \mathrm{E}$ & 1320 & 12 & W & 28.3 & 158 & 80 & 80 & 4.3 & 1106 & 1364 & 6.8 & 1 & $1994-1973$ (22) \\
\hline$F 52$ & $47^{\circ} 47^{\prime}$ & $5^{\circ} 04^{\prime} \mathrm{E}$ & 440 & 0 & - & 25.2 & 106 & 100 & 30.2 & 5.9 & 947 & 987 & 9 & 1 & $1994-1973(22)$ \\
\hline$F 54 a$ & $48^{\circ} 30^{\prime}$ & $6^{\circ} 42^{\prime} \mathrm{E}$ & 325 & 5 & $E$ & 27.1 & 95 & 120 & 29.1 & 6.2 & 888 & 1038 & 9.5 & 3 & 1994-1972 (23) \\
\hline$F 54 b$ & $48^{\circ} 38^{\prime}$ & $6^{\circ} 04^{\prime} \mathrm{E}$ & 390 & 2 & - & 26.3 & 99 & 60 & 28.3 & 6.2 & 885 & 823 & 9.8 & 1 & 1994-1981 (14) \\
\hline$F 55$ & $49^{\circ} 11^{\prime}$ & $5^{\circ} 00^{\prime} \mathrm{E}$ & 250 & 0 & - & 25.8 & 88 & 150 & 29.4 & 5.9 & 1000 & 965 & 9.6 & 3 & $1994-1980$ (15) \\
\hline$F 60$ & $49^{\circ} 19^{\prime}$ & $2^{\circ} 52^{\prime} \mathrm{E}$ & 138 & 0 & - & 26.6 & 62 & 160 & 26.8 & 6.6 & 920 & 717 & 10.1 & 2 & 1994-1982 (13) \\
\hline$F 64$ & $43^{\circ} 08^{\prime}$ & $0^{\circ} 39 \mathrm{~W}$ & 400 & 44 & NW & 26 & 67 & 137 & 28.8 & 5.3 & 1064 & 1299 & 12.7 & 2 & 1994-1977 (18) \\
\hline$F 65$ & $43^{\circ} 01^{\prime}$ & $0^{\circ} 26^{\prime} \mathrm{E}$ & 850 & 25 & NW & 29.1 & 160 & 180 & 180 & 6.4 & 1080 & 1114 & 11.6 & 2 & $1994-1972$ (23) \\
\hline$F 76$ & $49^{\circ} 42^{\prime}$ & $1^{\circ} 19^{\prime} \mathrm{E}$ & 210 & 0 & - & 24.5 & 87 & 90 & 29.9 & 6.5 & 776 & 930 & 9.9 & 2 & 1994-1974 (21) \\
\hline$F 81$ & $43^{\circ} 24^{\prime}$ & $2^{\circ} 10^{\prime} \mathrm{E}$ & 700 & 0 & - & 28.1 & 108 & 140 & 30.3 & 6.3 & 1219 & 1102 & 9.9 & 2 & 1994-1972 (23) \\
\hline$F 88$ & $48^{\circ} 06^{\prime}$ & $6^{\circ} 14^{\prime} \mathrm{E}$ & 400 & 3 & W & 27.5 & 68 & 100 & 25.4 & 5.9 & 877 & 1092 & 9.1 & 3 & $1994-1983(12)$ \\
\hline Qr 77 & $48^{\circ} 27^{\prime}$ & $2^{\circ} 42^{\prime} \mathrm{E}$ & 80 & 0 & - & 24.3 & 113 & 150 & 27.8 & 6.1 & 1009 & 719 & 10.7 & 2 & 1994-1985 (10) \\
\hline Qr 18 & $46^{\circ} 49^{\prime}$ & $2^{\circ} 34^{\prime} \mathrm{E}$ & 175 & 2 & NW & 26.9 & 58 & 180 & 17.7 & 4.6 & 1031 & 782 & 11 & 2 & $1994-1987$ (8) \\
\hline Qr 40 & $43^{\circ} 44^{\prime}$ & $0^{\circ} 50^{\prime} \mathrm{W}$ & 20 & 5 & $\mathrm{NE}$ & 25.2 & 46 & 140 & 25 & 5.6 & 1049 & 1010 & 13 & 1 & 1994-1984 (11) \\
\hline Qr 49 & $47^{\circ} 27^{\prime}$ & $0^{\circ} 01^{\prime} \mathrm{W}$ & 57 & 0 & - & 29.1 & 70 & 170 & 28.1 & 6.9 & 1085 & 665 & 11.5 & 1 & $1994-1983(12)$ \\
\hline Qr 55 & $49^{\circ} 01^{\prime}$ & $5^{\circ} 45^{\prime} \mathrm{E}$ & 220 & 0 & - & 23.9 & 100 & 150 & 20.1 & 5.9 & 929 & 827 & 9.4 & 1 & 1994-1972 (23) \\
\hline Qr 59 & $50^{\circ} 10^{\prime}$ & $3^{\circ} 45^{\prime} \mathrm{E}$ & 149 & 3 & - & 27.2 & 70 & 200 & 22.8 & 6.5 & 986 & 870 & 9.8 & 1 & 1994-1974 (21) \\
\hline Qr 65 & $43^{\circ} 12^{\prime}$ & $0^{\circ} 02^{\prime} \mathrm{W}$ & 370 & 12 & SE & 25.5 & 54 & 160 & 24.9 & 4.7 & 1042 & 965 & 12 & 1 & $1994-1986(9)$ \\
\hline Qr 71 & $46^{\circ} 58^{\prime}$ & $5^{\circ} 14^{\prime} \mathrm{E}$ & 190 & 0 & - & 26.3 & 67 & 190 & 25.6 & 6.5 & 1096 & 1006 & 11.3 & 1 & 1994-1972 (23) \\
\hline Qp 01 & $46^{\circ} 10^{\prime}$ & $5^{\circ} 14^{\prime} \mathrm{E}$ & 260 & 3 & - & 23.7 & 88 & 170 & 25.9 & 6.5 & 1015 & 1017 & 10.5 & 1 & $1994-1982(13)$ \\
\hline Qp 03 & $46^{\circ} 40^{\prime}$ & $2^{\circ} 43^{\prime} \mathrm{E}$ & 260 & 0 & - & 27.4 & 115 & 100 & 30.5 & 5.6 & 1080 & 802 & 10.5 & 2 & 1994-1965 (30) \\
\hline Qp 10 & $48^{\circ} 17^{\prime}$ & $4^{\circ} 27^{\prime} \mathrm{E}$ & 160 & 0 & - & 22.9 & 83 & 200 & 24.9 & 6.3 & 1010 & 778 & 10.4 & 1 & $1994-1987(8)$ \\
\hline Qp 18 & $47^{\circ} 15^{\prime}$ & $2^{\circ} 07 \mathrm{~W}$ & 176 & 1 & - & 26.3 & 78 & 150 & 28.2 & 5.9 & 1025 & 792 & 10.9 & 2 & $1994-1978$ (17) \\
\hline Qp 27 & $49^{\circ} 21^{\prime}$ & $1^{\circ} 03^{\prime} \mathrm{E}$ & 175 & 0 & - & 27.2 & 55 & 170 & 23.4 & 6.5 & 844 & 768 & 9.8 & 2 & 1994-1984 (11) \\
\hline Qp 35 & $48^{\circ} 10^{\prime}$ & $1^{\circ} 32^{\prime} \mathrm{W}$ & 80 & 0 & - & 26.3 & 101 & 120 & 29.3 & 6.1 & 893 & 764 & 11 & 2 & 1994-1966 (29) \\
\hline Qp 41 & $47^{\circ} 34^{\prime}$ & $1^{\circ} 15^{\prime} \mathrm{E}$ & 127 & 0 & - & 25.6 & 92 & 180 & 28.1 & 5.9 & 985 & 639 & 10.9 & 3 & 1994-1972 (23) \\
\hline Qp 51 & $49^{\circ} 01^{\prime}$ & $4^{\circ} 57^{\prime} \mathrm{E}$ & 180 & 2 & $S$ & 25.4 & 139 & 80 & 25.2 & 5.9 & 969 & 877 & 9.9 & 3 & 1994-1964 (31) \\
\hline Qp 57a & $48^{\circ} 52^{\prime}$ & $6^{\circ} 28^{\prime} \mathrm{E}$ & 320 & 4 & NE & 25.1 & 85 & 150 & 27.7 & 5 & 1009 & 719 & 10.7 & 1 & $1994-1970(25)$ \\
\hline Qp 57b & $49^{\circ} 00^{\prime}$ & $7^{\circ} 27^{\prime} \mathrm{E}$ & 320 & 15 & NW & 20.9 & 128 & 140 & 28.7 & 5.6 & 1009 & 719 & 10.7 & 3 & 1994-1964 (31) \\
\hline Qp 58 & $46^{\circ} 58^{\prime}$ & $3^{\circ} 39^{\prime} \mathrm{E}$ & 270 & 7 & SW & 24.1 & 66 & 150 & 23.5 & 6.2 & 1088 & 928 & 10.8 & 2 & 1994-1983 (12) \\
\hline Qp 60 & $49^{\circ} 23^{\prime}$ & $2^{\circ} 17 \mathrm{~W}$ & 55 & 1 & - & 26.5 & 60 & 140 & 25.3 & 6.5 & 855 & 674 & 10.2 & 1 & 1994-1979 (16) \\
\hline Qp 61 & $48^{\circ} 31^{\prime}$ & $0^{\circ} 40^{\prime} \mathrm{E}$ & 220 & 5 & SE & 25.8 & 88 & 110 & 26.9 & 6.7 & 889 & 773 & 10.1 & 2 & 1994-1981 (14) \\
\hline Qp 68 & $47^{\circ} 41^{\prime}$ & $7^{\circ} 28^{\prime} \mathrm{E}$ & 256 & 0 & - & 27.9 & 137 & 80 & 22 & 5.6 & 891 & 811 & 10.1 & 3 & $1994-1970(25)$ \\
\hline Qp 72 & $47^{\circ} 46^{\prime}$ & $0^{\circ} 22^{\prime} \mathrm{E}$ & 170 & 0 & - & 22 & 64 & 170 & 24.1 & 5.9 & 952 & 719 & 10.9 & 3 & $1994-1987(8)$ \\
\hline Qp 81 & $44^{\circ} 02^{\prime}$ & $1^{\circ} 44^{\prime} \mathrm{E}$ & 300 & 18 & SE & 22.1 & 98 & 100 & 27.8 & 5.3 & 1246 & 869 & 12.0 & 2 & 1994-1972 (23) \\
\hline Qp 86 & $46^{\circ} 37^{\prime}$ & $0^{\circ} 29^{\prime} \mathrm{E}$ & 116 & 4 & NW & 24 & 82 & 80 & 25.1 & 6.0 & 1121 & 758 & 11.5 & 3 & $1994-1985$ (10) \\
\hline Qp 88 & $48^{\circ} 01^{\prime}$ & $6^{\circ} 02^{\prime} \mathrm{E}$ & 330 & 0 & - & 24.8 & 129 & 200 & 26.4 & 5.7 & 877 & 1103 & 8.99 & 2 & 1994-1964 (31) \\
\hline
\end{tabular}


Table S1.1. Continued

\begin{tabular}{|c|c|c|c|c|c|c|c|c|c|c|c|c|c|c|c|}
\hline ID & $\begin{array}{l}\text { Lat. } \\
(\mathrm{N})\end{array}$ & $\begin{array}{l}\text { Long. } \\
\text { (E/W) }\end{array}$ & $\begin{array}{c}\text { Elev. } \\
(\mathrm{m})\end{array}$ & $\begin{array}{c}\text { Slope } \\
\%\end{array}$ & Exp. & LNC & Age & $\begin{array}{c}\text { SWHC } \\
(\mathrm{mm})\end{array}$ & $\begin{array}{c}\mathrm{H} \\
(\mathrm{m})\end{array}$ & LAI & $\begin{array}{l}\text { ETP } \\
(\mathrm{mm})\end{array}$ & $\begin{array}{l}\text { Prec. } \\
(\mathrm{mm})\end{array}$ & $\mathrm{T}\left({ }^{\circ} \mathrm{C}\right)$ & SNA & $\begin{array}{c}\text { period } \\
\text { (nb. of years) }\end{array}$ \\
\hline$P 39 a$ & $46^{\circ} 11^{\prime}$ & $2^{\circ} 59^{\prime} \mathrm{E}$ & 970 & 10 & SE & 14 & 58 & 90 & 30.4 & 6.9 & 942 & 1865 & 7.5 & 1 & $1994-1973(22)$ \\
\hline$P 39 b$ & $44^{\circ} 07^{\prime}$ & $5^{\circ} 47^{\prime} \mathrm{E}$ & 1210 & 8 & W & 12.9 & 111 & 80 & 23.6 & 5.4 & 931 & 2100 & 5.7 & 1 & $1994-1979$ (16) \\
\hline$P 71$ & $42^{\circ} 55^{\prime}$ & $1^{\circ} 16^{\prime} \mathrm{E}$ & 600 & 20 & SE & 13.1 & 48 & 100 & 27 & 5.8 & 1055 & 936 & 9.8 & 3 & $1994-1980$ (15) \\
\hline$P 73$ & $49^{\circ} 10^{\prime}$ & $0^{\circ} 51^{\prime} \mathrm{W}$ & 1700 & 40 & NW & 12.7 & 182 & 110 & 22.7 & 4.2 & 869 & 1263 & 4.1 & 2 & 1994-1979 (16) \\
\hline$P 74$ & $47^{\circ} 48^{\prime}$ & $4^{\circ} 51^{\prime} \mathrm{E}$ & 1200 & 20 & W & 13.8 & 73 & 150 & 30 & 8.4 & 939 & 1737 & 7.2 & 2 & $1994-1978$ (17) \\
\hline$P 88$ & $44^{\circ} 55^{\prime}$ & $5^{\circ} 17^{\prime} \mathrm{E}$ & 660 & 20 & SW & 14.2 & 89 & 100 & 35.5 & 6.1 & 867 & 1458 & 8.5 & 2 & $1994-1980$ (15) \\
\hline Qi 34 & $43^{\circ} 44^{\prime}$ & $3^{\circ} 35^{\prime} \mathrm{E}$ & 270 & 0 & - & 12 & 68 & 113 & 6 & 2.4 & 1417 & 907 & 13.4 & - & 2008-1966 (43) \\
\hline
\end{tabular}




\section{Supplement 2. Reconstruction of the historical circumference trajectories}

The historical circumference $(\mathrm{CBH})$ trajectories were obtained on the 49 studied plots by combining forest inventories and tree-ring series. Dendrochronological sampling was conducted after the completion of the forest inventories (Figure S2.1), so that the calculation of historical $\mathrm{CBHs}$ inventories could rely on tree-ring series information. 30 trees were cored in the RENECOFOR network (Lebourgeois 1997) and 12 were cored in the Puechabon site (J.M. Limousin, unpublished data). Past $\mathrm{CBH}$ was annually calculated from the initial forest inventory backward. Reconstruction stopped when a sharp decrease of $\mathrm{CBH}$ growth indicated nonreported past silvicultural intervention or when the associated stand age felt below 25 years (Figure S.2.1).

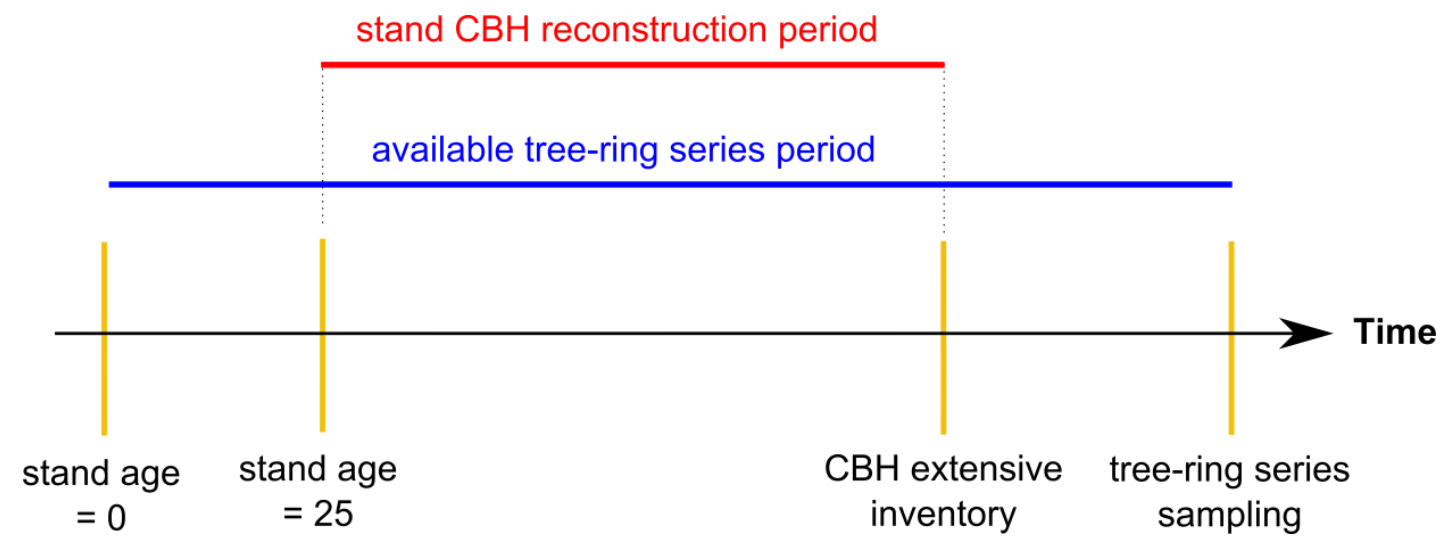

Figure S2.1. Illustration of the growth measurement timing.

First, the $\mathrm{CBH}$ trajectories of the cored trees were calculated using tree rings and the $\mathrm{CBHs}$ measured at the sampling time. Annual basal area increments were then calculated as follows.

$B A I_{t, i}=\frac{1}{4 \pi}\left(C B H_{t, i}{ }^{2}-C B H_{t, i-1}{ }^{2}\right) \quad$ (Eq. S2.1) 
where $B A I_{t, i}$ is the basal area increment observed on a tree $\mathrm{t}$, in a year $\mathrm{i}$.

In a second step, BAI and $\mathrm{CBH}$ data were used to calibrate - for each year and each plot - an empirical tree competition model (Deleuze et al. 2004), following the approach described in (Guillemot et al. 2014). The considered model can be written as follows.

$B A I_{t, i}=\frac{\gamma_{i}}{2} \times\left(C B H_{t, i}-m \sigma_{i}+\sqrt{\left(m \sigma_{i}+C B H_{t, i}\right)^{2}-4 \sigma_{i} \times C B H_{t, i}}\right) \quad$ (Eq. S2.2)

where $\mathrm{CBH}_{\mathrm{t}, \mathrm{i}}$ is the circumference at breast height of a given tree $t$ in a year $\mathrm{I}$, and $\mathrm{BAI}_{\mathrm{t}, \mathrm{i}}$ is its corresponding annual basal area increment. $\sigma$ and $\gamma$ are the annually calibrated parameters. In this model, only trees with a circumference at breast height $(\mathrm{CBH})$ above the threshold $\sigma_{i}$, which can be interpreted as the minimum circumference for direct access to sunlight, have a significant growth. Overstory trees then grow proportionally to their sizes, following a slope coefficient $\gamma_{i}$ (Fig. S2.2). $m$ is a smoothing parameter.

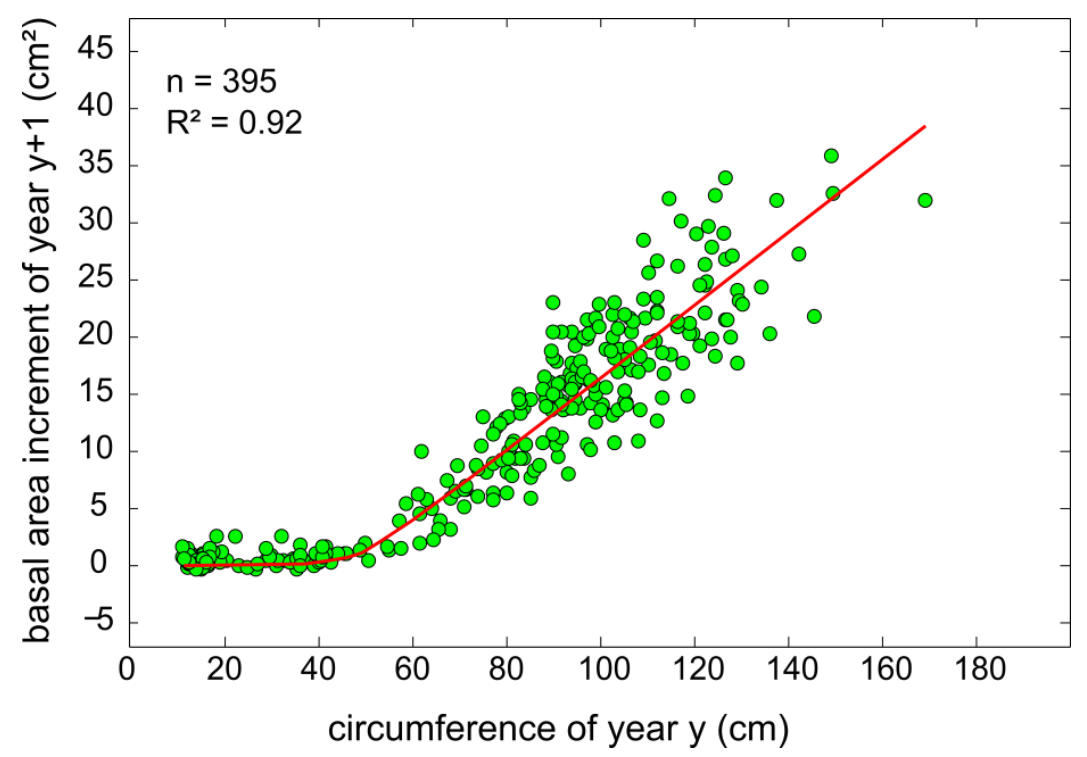

Figure S2.2. Illustration of the tree competition model described in Eq. S2.2. Data were obtained from extensive inventories lead in 2000 and 2009 in plot F03 (Guillemot et al. 2014). 
The calibrated model was then used to infer the BAls of all the trees of the initial $\mathrm{CBH}$ stand distribution. The whole calculation followed an algorithm displayed in Figure S2.3.

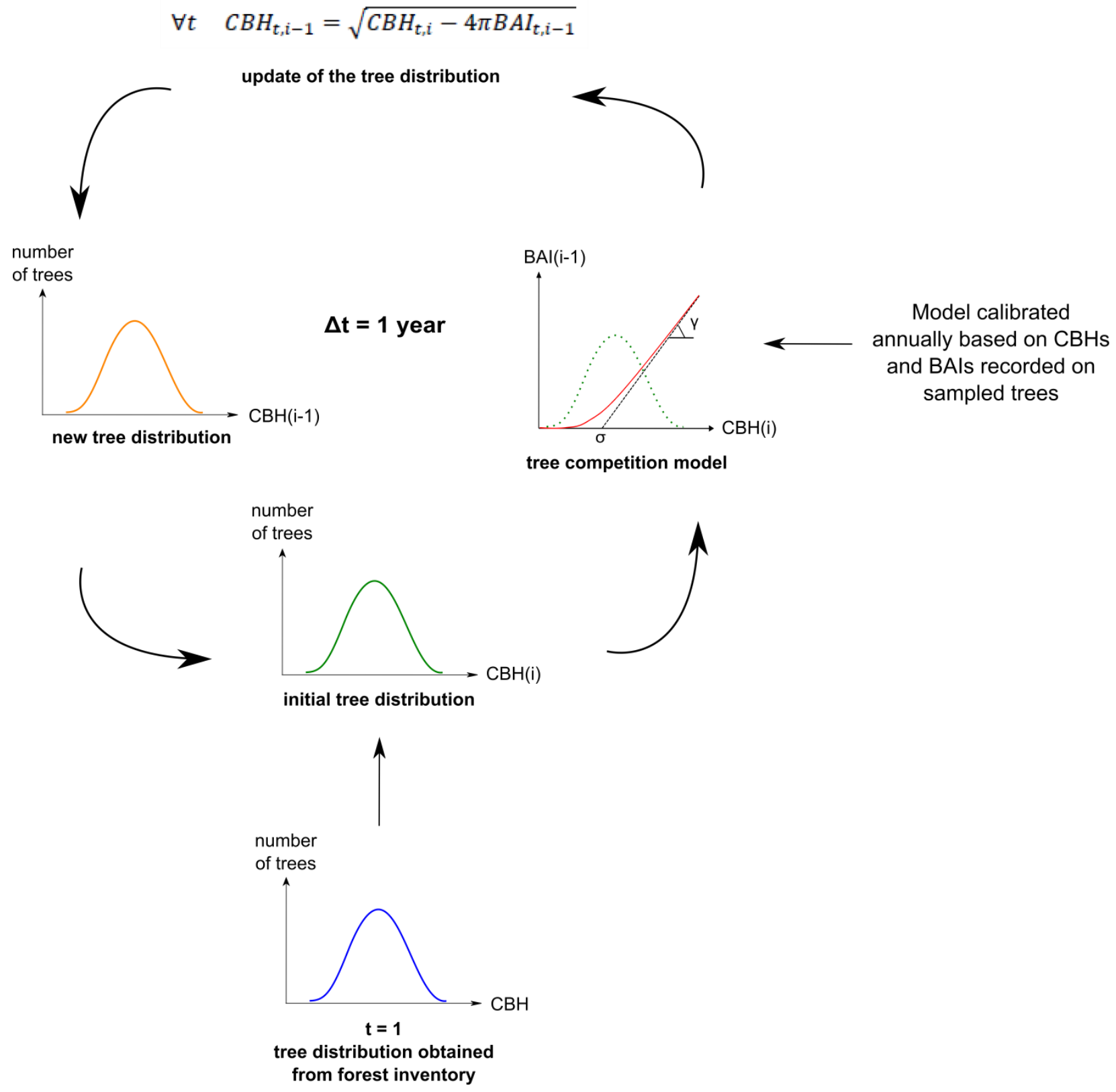

Figure S2.3. Illustration of the algorithm used to reconstruct historical circumference trajectories. 


\section{Supplement 3. Functions used in the calculation of woody biomass}

Tree woody biomass calculation was based on distinct procedure for $F$. sylvatica, $Q$. petraea and $P$. abies on one hand, and $Q$. ilex on other hand.

\subsection{F. sylvatica, Q. petraea and P. abies}

\section{- Top height}

- F. sylvatica curves

We used the curves suggested by Bontemps, Hervé \& Dhôte (2009) which account for the longterm forest productivity trend induced by global changes. The dominant height at the age $\mathrm{t}, H_{t}$ $(\mathrm{m})$, is described as follows.

$H_{t}=m 1 \cdot \exp \left(-\left(p f \cdot m 2 \cdot \operatorname{chprod}\left(\text { date }_{0}+t\right)+\left(\ln \left(\frac{a}{H_{t-1}}\right)\right)^{-\frac{1}{m 3}}\right)^{-m 3}\right)$

with

$$
\left\{\begin{array}{c}
\text { if } 1900<\text { date }<2000 \text { then chprod }(\text { date })=1+m 4 .(\text { date }-1900)+m 5 .(\text { date }-1900)^{2} \\
\text { if date } \leq 1900 \text { then } \operatorname{chprod}(\text { date })=1 \\
\text { if date } \geq 2000 \text { then chprod }(\text { date })=\operatorname{chprod}(2000)
\end{array}\right.
$$

- Q. petraea curve

Similarly, the curve suggested by Bontemps et al. (2012) also includes explicitly the changes in forest productivity.

$\frac{d H}{d t}=f 2\left(t-t_{b}\right) \cdot p_{f} \cdot f 1(H) \quad($ Eq. S3.2)

where $H$ is the top height $(m), t$ is date, tb is a reference date (here $t_{b}=1900$ ).

$f 1(H)=\frac{\left(\frac{H}{K_{s}}\right)^{m 1 \cdot m 2}}{\left(1-m 1+m 1\left(\frac{H}{m 3}\right)^{m 2}\right)}$ 
$f 2(t)=1+d 1 \cdot u+d 2 \cdot u^{2}+d 3 \cdot u^{3}+\sum_{k=1}^{4} p_{k} \cdot \max (u-20 \cdot k, 0)^{3}+\sum_{k=0}^{1} \cdot p m_{k} \cdot \min (u-20 \cdot k, 0)^{3}$ (Eq. S3.4)

with $u=t-1900$

Equation S3.3 was integrated numerically using Range-Kutta 4 method.

- P. abies curve

We used the curve suggested in Seynave et al. (2005).

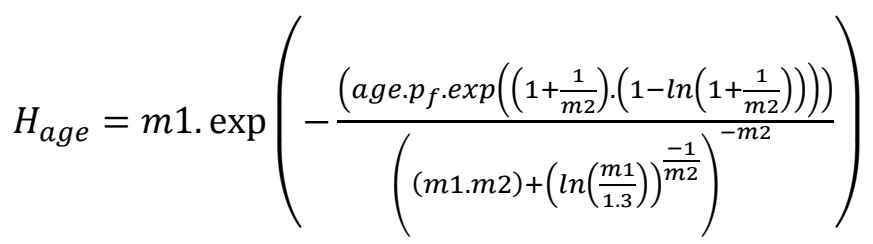

(Eq. S3.5)

where $H_{\text {age }}$ is the stand dominant height $(\mathrm{m})$ at the corresponding age.

- Parameterization and initialization

The parameterization of Eq. S3.1, S3.3 and S3.5 are provided in Table S3.1.

Table S3.1. Parameterization of the top height models

\begin{tabular}{cc|c}
\hline Species & & Parameter values \\
\hline & Eastern & $\mathrm{m} 1=68.7 ; \mathrm{m} 2=0.028 ; \mathrm{m} 3=0.823 ; \mathrm{m} 4=2.03 .10^{-3} ;$ \\
& France & $\mathrm{m} 5=3.96 .10^{-5}$ \\
& Western & $\mathrm{m} 1=44.2 ; \mathrm{m} 2=0.032 ; \mathrm{m} 3=1.647 ; \mathrm{m} 4=1.245 .10^{-3} ;$ \\
France & $\mathrm{m} 5=1.74 .10^{-5}$ \\
& $\mathrm{~K}_{\mathrm{s}}=6.1 ; \mathrm{m} 1=0.138 ; \mathrm{m} 2=2.36 ; \mathrm{d} 1=0.2 .10^{2} ; \mathrm{d} 2=0.027 .10^{3} ; \mathrm{d} 3=-$ \\
& $0.063 .10^{4} ; \mathrm{p} 1=0.284 .10^{4} ; \mathrm{p} 2=-0.622 ; \mathrm{p} 3=1.076 ; \mathrm{p} 4=-1.545 ;$ \\
Q. petraea & $\mathrm{pm} 0=0.024 ; \mathrm{pm} 1=-0.076$ \\
& $\mathrm{~m} 1=50.7 ; \mathrm{m} 2=1.08$ \\
\hline
\end{tabular}


F. sylvativa and Q. petraea curves require initialization, defined as follows: $H_{a g e=0}=0.3 \mathrm{~m}$.

The parameter $p_{\mathrm{f}}$ in Eq. S3.1, S3.2 and S3.5 is the site-specific fertility parameter. $\mathrm{p}_{\mathrm{f}}$ values have been defined by calibrated the curves on height and age measurements. The resulting curves are displayed in Figure S3.1.

\section{- Individual height}

The height of each tree is then calculated using the hyperbolic model suggested by Dhôte and de Hercé (1994):

$H=1.3+\frac{\left(\left(H_{0}-1.3+p_{2} \cdot C B H\right)-\sqrt{\left.H_{0}-1.3+p_{2} \cdot C B H\right)^{2}-4 \cdot p_{3} \cdot p_{2} \cdot\left(H_{0}-1.3\right) \cdot C B H}\right.}{2 \cdot p_{3}} \quad$ (Eq. S3.6)

where $\mathrm{H}$ is the height of a given tree with a circumference $\mathrm{CBH}$ and $\mathrm{H}_{0}$ is the stand dominant height.

$p_{2}$ and $p_{3}$ parameters were defined per plot using height and $C B H$ measurements.

\section{- Individual above-ground volume equations}

Tree above-ground volumes were calculated from $\mathrm{CBH}$ and $\mathrm{H}$, using the equations established by Vallet et al. (2006):

$V=$ form $\frac{1}{40000 \pi} C B H^{2} . H \quad($ Eq. S3.7) 

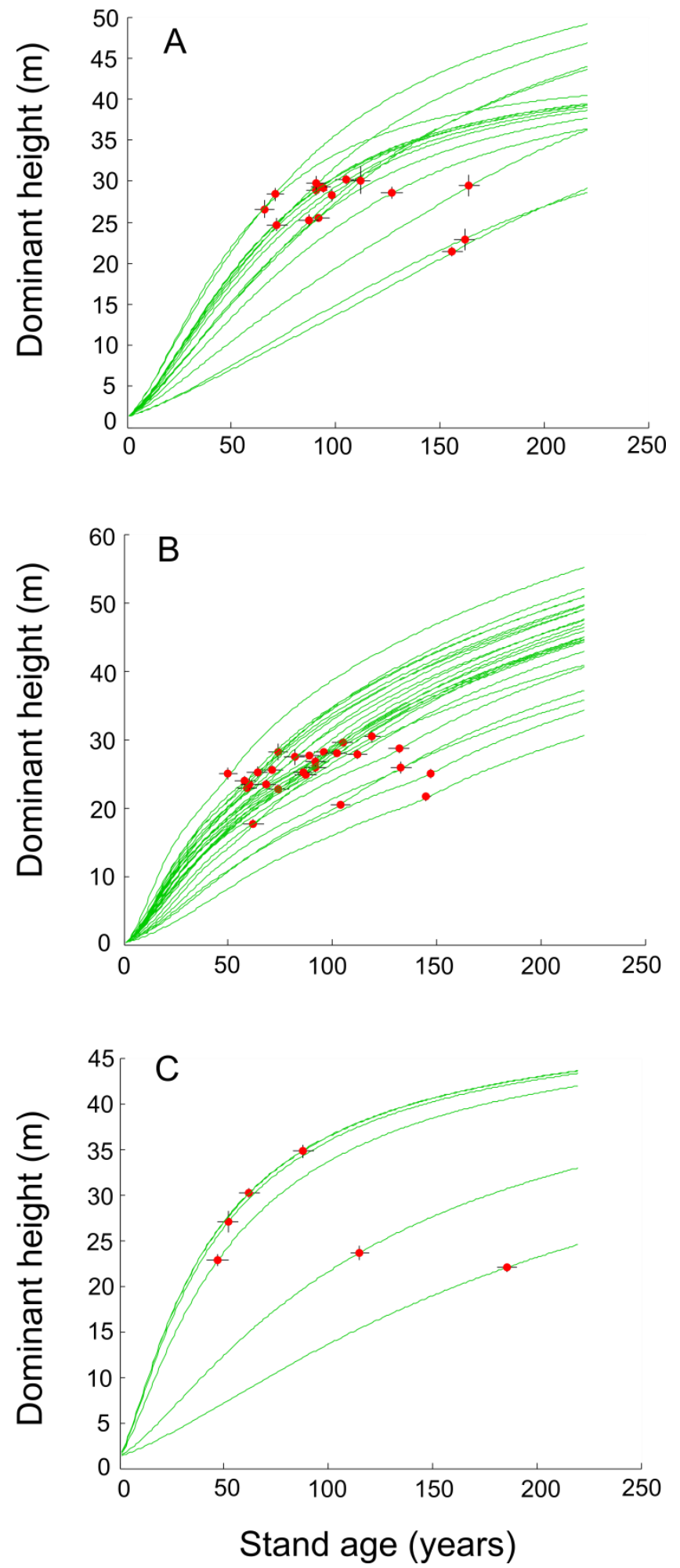

Figure S3.1. Site-specific top height curves for F. sylvatica (A), Q. petraea (B) and P. abies $(C)$. Points and error bar correspond to age and height measurements. 
where

$\mathrm{V}$ is the total above ground tree volume and

form $=(\alpha+\beta \cdot C B H+\gamma \cdot h d n)\left(1+\frac{\delta}{C B H^{2}}\right) \quad($ Eq. S3.8)

with hdn $=\mathrm{CBH}^{1 / 2} / \mathrm{H}$.

Parameterization of Eq. (S3.8) is provided in Table S3.2.

Table S3.2. Parameterization of the tree volume equations

\begin{tabular}{cccc}
\hline Parameter & Q. petraea & F. sylvatica & P. abies \\
\hline$\alpha$ & 0.471 & 0.395 & 0.631 \\
$\beta$ & -0.000345 & 0.000266 & -0.000946 \\
$\gamma$ & 0.377 & 0.421 & 0 \\
$\delta$ & 0 & 45.4 & 0 \\
\hline
\end{tabular}

\section{- Wood density models}

Wood density models typically relates the density of a tree ring formed in year $\mathrm{i}\left(W \mathrm{D}_{\mathrm{i}}\right)$ to tree age $\left(\mathrm{age}_{\mathrm{i}}\right)$ and ring width $\left(\mathrm{RW}_{\mathrm{i}}\right)$ (Guilley, Hervé \& Nepveu 2004; Bergès, Nepveu \& Franc 2008).

We used density models established by:

- $\quad$ Zhang et al. (1993) for Q. petraea, with WD models as

$W D_{i}=\frac{a+\text { b.age }_{i}-\left(\frac{c}{R W_{i}}\right)-\left(\frac{\text { d.age }_{i}}{R W_{i}}\right)}{1.235} \quad$ (Eq. S3.9)

- Bouriaud et al. (2004) for F. sylvatica, with

$W D_{i}=\frac{a-b . a g e+\frac{c}{R W_{i}}}{1.3} \quad($ Eq. S3.10)

- Wilhelmsson et al. (2002) for P. abies

$$
W D_{i}=a+e \cdot(\ln (\text { age }))^{b}-c \cdot \frac{R W_{i}}{a g e \times T_{\text {sum }}}+\frac{d \cdot T s u m}{\frac{1}{2} \cdot \frac{R W_{i}}{a g e}+2.3} \quad(\text { Eq. S3.11) }
$$

with 
$T_{\text {sum }}=4922.1-60.367 * 48-0.837 * 1000$

Parameterization of equations S3.9, S3.10 and S3.11 is provided in Table S3.3.

Table S3.3. Parameterization of the wood density models

\begin{tabular}{cccc}
\hline Parameter & Q. petraea & F. sylvatica & $P$. abies \\
\hline a & 817.9 & 789 & 304.3 \\
b & 0.0038 & 0.86 & 0.5 \\
c & 98.927 & 0.32 & -444.13 \\
d & 0.922 & - & 0.295 \\
e & 1.235 & 1.3 & 10.4437 \\
\hline
\end{tabular}

Annual wood density was calculated for all the available dendrochronological tree ring series and use to convert the corresponding annual volume increment in annual dry matter increment. The dry matter mass was then converted to carbon biomass assuming $50 \%$ carbon content in woody tissues (Pignard et al. 2000).

\section{- Individual total volume calculation}

Total tree woody biomass of all sites was obtained from above-ground biomass using agerelated species-specific relationship after checking for no additional effect of stand density and mean tree size (data not shown).

$$
T W B=A W B+A W B \times R S(\text { age })
$$

with TBW the total woody biomass, AWB the above-ground woody biomass and RS the rootshoot ratio, function of stand age.

We used root-shoot model established by Genet, Bréda \& Dufrêne (2010) for Q. petraea and F. sylvatica and Lehtonen et al. (2004) for P. abies. 
$R S(a g e)=a+b \cdot \exp (c \times a g e) \quad($ Eq. S3.12)

Table S3.4. Parameterization of the root-shoot models

\begin{tabular}{cccc}
\hline Parameter & Q. petraea & F. sylvatica & P. abies \\
\hline a & 0.1893 & 0.183 & 0.0838 \\
b & 0.8295 & 1.6259 & -0.0365 \\
c & -0.0496 & -0.3174 & -0.01 \\
\hline
\end{tabular}

\subsection{Q. ilex}

The calculation of AWB for Q. ilex benefited from the work of Rambal et al.(2004) conducted on the studied plot (Puechabon site). $\mathrm{AWB}_{\mathrm{i}}$ of a given tree $\mathrm{i}$ was related directly to $\mathrm{CBH}_{\mathrm{i}}$ using a relationship calibrated on 10 stems.

$A W B=191.6 \times\left(\frac{C B H}{\pi}\right)^{2.171} \quad($ Eq. S3.13)

The Puechabon site is managed as a coppice, with $Q$. ilex stems sprouting from the stumps after cutting. For this reason, root biomass is there much more important than shoot biomass, at least during the first part of the coppice rotation. We assumed consequently no root biomass growth over the studied period in this site and we calculated the corresponding annual woody biomass increments directly from AWB and not from TWB. 


\section{Supplement 4. Annual woody biomass increment features}

We calculated annual woody biomass increments as follows for the RENECOFOR plots.

$A W B I_{i}=T W B_{i}-T W B_{i-1} \quad($ Eq. S4.1)

where i corresponds to year.

For the Puechabon site, AWBIs were calculated as follows.

$A W B I_{i}=A W B_{i}-A W B_{i-1} \quad($ Eq. S4.2)

Characteristics of the calculated AWBIs are presented in Table S4.1. The mean sensitivity and first order auto-correlation coefficient were calculated on detrended data to measure, respectively, the year-to-year variability and the lagged influence of growth of the previous year on the current year growth (Fritts 2012). 
Table S4.1. Site-specific characteristics of the annual woody biomass increments (AWBI). $R^{2}$ and RMSE (coefficient of determination and root mean square error) correspond to the goodness of fit of the tree competition model used in the $\mathrm{CBH}$ reconstruction (mean \pm .standard error), mean $A W B I$ is calculated on raw data, MS and $A C$ are the mean sensitivity and the firstorder autocorrelation coefficient of the detrended AWBI series, respectively.

\begin{tabular}{|c|c|c|c|c|c|}
\hline ID & $\mathrm{R}^{2}(\%)$ & $\begin{array}{l}\text { RMSE } \\
\left(\mathrm{gC} \cdot \mathrm{m}^{-2}\right)\end{array}$ & $\begin{array}{c}\text { mean AWBI } \\
\left(\mathrm{gC} \cdot \mathrm{m}^{-2}\right)\end{array}$ & $\begin{array}{c}\text { MS } \\
\text { (unitless) }\end{array}$ & $\begin{array}{c}\mathrm{AC} \\
\text { (unitless) }\end{array}$ \\
\hline$F 03$ & $36.8 \pm 3.9$ & $10.0 \pm 1.3$ & 379.7 & 0.19 & 0.40 \\
\hline F 04 & $61.6 \pm 14.3$ & $5.1 \pm 2.3$ & 267.0 & 0.17 & 0.15 \\
\hline$F 09$ & $52.0 \pm 13.9$ & $9.8 \pm 0.9$ & 158.7 & 0.22 & 0.18 \\
\hline$F 14$ & $54.2 \pm 14.4$ & $5.4 \pm 1.9$ & 262.8 & 0.23 & 0.36 \\
\hline$F 21$ & $35.0 \pm 5.9$ & $13.3 \pm 1.9$ & 204.5 & 0.23 & 0.36 \\
\hline$F 26$ & $54.0 \pm 11.6$ & $9.3 \pm 0.6$ & 160.1 & 0.22 & 0.28 \\
\hline$F 52$ & $41.6 \pm 12.5$ & $5.5 \pm 1.6$ & 273.7 & 0.26 & 0.18 \\
\hline$F 54 a$ & $60.7 \pm 16.1$ & $9.7 \pm 2.4$ & 391.1 & 0.23 & 0.16 \\
\hline$F 54 b$ & $67.1 \pm 11.5$ & $7.7 \pm 1.9$ & 231.3 & 0.21 & 0.29 \\
\hline$F 55$ & $46.9 \pm 17.8$ & $9.9 \pm 2.0$ & 379.0 & 0.12 & 0.20 \\
\hline$F 60$ & $74.1 \pm 18.1$ & $6.3 \pm 1.6$ & 405.7 & 0.17 & 0.32 \\
\hline$F 64$ & $52.4 \pm 13.1$ & $8.4 \pm 2.3$ & 415.1 & 0.17 & 0.34 \\
\hline$F 65$ & $59.3 \pm 12.2$ & $7.3 \pm 1.3$ & 237.9 & 0.15 & 0.24 \\
\hline$F 76$ & $36.5 \pm 9.9$ & $8.8 \pm 1.8$ & 278.2 & 0.19 & 0.41 \\
\hline$F 81$ & $38.8 \pm 13.3$ & $7.5 \pm 1.5$ & 279.9 & 0.18 & 0.37 \\
\hline$F 88$ & $38.9 \pm 5.3$ & $6.7 \pm 1.2$ & 381.1 & 0.13 & 0.45 \\
\hline Qr 77 & $42.6 \pm 16.1$ & $9.7 \pm 2.4$ & 238.7 & 0.15 & 0.67 \\
\hline Qr 18 & $68.6 \pm 6.2$ & $3.6 \pm 1.3$ & 247.2 & 0.17 & 0.20 \\
\hline Qr 40 & $63.5 \pm 15.6$ & $8.7 \pm 1.7$ & 351.9 & 0.18 & 0.26 \\
\hline Qr 49 & $44.5 \pm 7.0$ & $10.8 \pm 1.7$ & 409.3 & 0.13 & 0.46 \\
\hline Qr 55 & $30.7 \pm 10.9$ & $7.6 \pm 1.8$ & 104.0 & 0.15 & 0.23 \\
\hline Qr 59 & $38.0 \pm 13.8$ & $5.6 \pm 1.6$ & 228.3 & 0.22 & 0.20 \\
\hline Qr 65 & $77.8 \pm 7.5$ & $4.9 \pm 1.3$ & 296.5 & 0.23 & 0.24 \\
\hline Qr 71 & $35.4 \pm 1.4$ & $6.7 \pm 1.6$ & 303.4 & 0.17 & 0.25 \\
\hline Qp 01 & $47.0 \pm 12.7$ & $5.1 \pm 1.5$ & 264.2 & 0.15 & 0.12 \\
\hline Qp 03 & $70.8 \pm 11.9$ & $4.3 \pm 0.9$ & 278.7 & 0.14 & 0.17 \\
\hline Qp 10 & $34.8 \pm 7.6$ & $7.6 \pm 1.6$ & 260.9 & 0.12 & 0.28 \\
\hline Qp 18 & $37.9 \pm 5.8$ & $6.9 \pm 1.8$ & 370.4 & 0.15 & 0.33 \\
\hline Qp 27 & $87.4 \pm 9.1$ & $5.4 \pm 1.5$ & 303.3 & 0.14 & 0.16 \\
\hline Qp 35 & $35.0 \pm 10.1$ & $6.5 \pm 1.5$ & 307.4 & 0.12 & 0.22 \\
\hline Qp 41 & $61.8 \pm 19.6$ & $5.9 \pm 0.8$ & 276.6 & 0.19 & 0.31 \\
\hline Qp 51 & $73.5 \pm 17.0$ & $5.9 \pm 0.9$ & 184.1 & 0.13 & 0.39 \\
\hline Qp 57a & $57.2 \pm 13.9$ & $3.8 \pm 1.1$ & 355.1 & 0.18 & 0.32 \\
\hline Qp 57b & $77.8 \pm 9.5$ & $4.8 \pm 0.6$ & 175.5 & 0.13 & 0.28 \\
\hline Qp 58 & $64.2 \pm 9.8$ & $6.2 \pm 0.9$ & 345.3 & 0.11 & 0.27 \\
\hline Qp 60 & $63.9 \pm 10.3$ & $4.7 \pm 1.1$ & 344.9 & 0.19 & 0.15 \\
\hline Qp 61 & $41.9 \pm 6.0$ & $4.6 \pm 0.7$ & 316.9 & 0.10 & 0.18 \\
\hline Qp 68 & $36.4 \pm 4.5$ & $7.5 \pm 2.0$ & 99.7 & 0.18 & 0.11 \\
\hline Qp 72 & $65.6 \pm 9.7$ & $4.8 \pm 1.4$ & 370.9 & 0.17 & 0.14 \\
\hline Qp 81 & $54.0 \pm 22.4$ & $3.7 \pm 1.1$ & 197.8 & 0.18 & 0.18 \\
\hline Qp 86 & $60.0 \pm 11.3$ & $6.2 \pm 1.2$ & 343.1 & 0.19 & 0.25 \\
\hline Qp 88 & $35.2 \pm 13.1$ & $5.7 \pm 1.9$ & 209.3 & 0.15 & 0.40 \\
\hline$P 39 a$ & $36.2 \pm 18.3$ & $10.0 \pm 2.3$ & 472.4 & 0.16 & 0.29 \\
\hline$P 39 b$ & $46.6 \pm 10.9$ & $5.1 \pm 0.9$ & 236.2 & 0.14 & 0.32 \\
\hline$P 71$ & $47.8 \pm 14.7$ & $9.8 \pm 2.5$ & 318.5 & 0.20 & 0.34 \\
\hline$P 73$ & $69.8 \pm 15.8$ & $5.4 \pm 0.8$ & 207.8 & 0.15 & 0.31 \\
\hline$P 74$ & $45.2 \pm 14.9$ & $13.3 \pm 2.0$ & 475.7 & 0.16 & 0.35 \\
\hline$P 88$ & $63.8 \pm 12.8$ & $9.3 \pm 1.6$ & 365.6 & 0.13 & 0.31 \\
\hline Qi 34 & $59.3 \pm 14.2$ & $9.2 \pm 1.2$ & 101.9 & 0.35 & 0.12 \\
\hline
\end{tabular}




\section{Supplement 5. Classes of soil nutrient availability}

Table S5.1. Soil characteristics of the studied plots. $\mathrm{C} / \mathrm{N}$ : carbon-nitrogen biomass ratio, T/S: percent base saturation, CEC: cationic exchange capacity, SNA: soil available nutrient classes ( $1=$ high, $2=$ medium, $3=$ =low nutrient availability).

\begin{tabular}{ccccc}
\hline ID & C/N & T/S & CEC & SNA \\
\hline$F 03$ & 14.5 & 9.8 & 4.2 & 2 \\
$F 04$ & 13.2 & 99.9 & 29.4 & 1 \\
$F 09$ & 14.8 & 13.2 & 5.3 & 3 \\
$F 14$ & 15.6 & 9.8 & 4.2 & 3 \\
$F 21$ & 15.0 & 99.9 & 42.3 & 1 \\
$F 26$ & 11.9 & 99.9 & 39.8 & 1 \\
$F 52$ & 13.3 & 99.8 & 30.9 & 1 \\
$F 54 a$ & 15.0 & 19.9 & 3.4 & 3 \\
$F 54 b$ & 12.6 & 99.7 & 38.3 & 1 \\
$F 55$ & 17.7 & 11.9 & 3.0 & 3 \\
$F 60$ & 13.0 & 99.9 & 13.7 & 2 \\
$F 64$ & 10.5 & 60.7 & 6.6 & 2 \\
$F 65$ & 11.3 & 10.5 & 5.3 & 2 \\
$F 76$ & 13.7 & 9.0 & 3.3 & 2 \\
$F 81$ & 14.2 & 12.9 & 4.4 & 2 \\
$F 88$ & 16.2 & 12.6 & 3.8 & 3 \\
\hline Qr 77 & 14.8 & 34.8 & 1.05 & 2 \\
Qr 18 & 17.8 & 88.6 & 14.5 & 2 \\
Qr 40 & 11.6 & 73.8 & 2.75 & 1 \\
Qr 49 & 10.7 & 39.1 & 1.2 & 1 \\
Qr 55 & 12.9 & 86.0 & 15.3 & 1 \\
Qr 59 & 12.7 & 42.1 & 6.5 & 1 \\
Qr 65 & 10.2 & 26 & 2.8 & 1 \\
Qr 71 & 14.6 & 54.0 & 4.4 & 1 \\
Qp 01 & 12.8 & 13.5 & 2.8 & 1 \\
Qp 03 & 16.8 & 23.9 & 1.5 & 2 \\
Qp 10 & 13.6 & 23.2 & 5.8 & 1 \\
Qp 18 & 19.5 & 11.8 & 1.4 & 2 \\
Qp 27 & 14.9 & 20.1 & 6.3 & 2 \\
Qp 35 & 15.2 & 7.7 & 2.8 & 2 \\
Qp 41 & 17.8 & 16.2 & 3.8 & 3 \\
Qp 51 & 19.7 & 25.9 & 6.7 & 3 \\
Qp 57a & 12.0 & 29.1 & 3.9 & 1 \\
Qp 57b & 23.6 & 7.5 & 2.0 & 3 \\
Qp 58 & 14.9 & 29.3 & 3.4 & 2 \\
Qp 60 & 13.4 & 36.9 & 2.6 & 1 \\
Qp 61 & 15.8 & 31.3 & 6.8 & 2 \\
Qp 68 & 16.1 & 21.9 & 3.5 & 3 \\
Qp 72 & 25.3 & 11.9 & 2.9 & 3 \\
Qp 81 & 15.9 & 23.2 & 6.2 & 2 \\
Qp 86 & 26.0 & 12.0 & 2.4 & 3 \\
Qp 88 & 15.9 & 20.8 & 4.5 & 2 \\
\hline P 39a & 10.9 & 98.1 & 26.8 & 1 \\
P 39b & 10.9 & 98.1 & 26.8 & 1 \\
P71 & 12.3 & 4.5 & 4.0 & 3 \\
P 73 & 15.7 & 34.5 & 4.0 & 2 \\
P 74 & 12.4 & 98.1 & 14.1 & 2 \\
P 88 & 15.3 & 14.3 & 4.0 & 2 \\
\hline Qi34 & - & - & - & - \\
\hline & & & &
\end{tabular}


Supplement $\mathbf{S 6}$. Species-specific aggregation periods of $\mathrm{C}$ fluxes used in the analyses

The period we retained for the aggregation of $C$ fluxes in the present studies was based on reported measurement on species-specific wood growth phenology (Table S6.1).

Table S6.1. Aggregation periods of carbon fluxes. Values are day of the year.

\begin{tabular}{lccl}
\hline Species & Start & End & Reference \\
\hline F. sylvatica & 110 & 270 & Skomarkova et al. 2006 \\
Q. petraea & 90 & 260 & Michelot et al. 2012 \\
P. abies & 100 & 300 & $\begin{array}{l}\text { H. Cuny, C. Rathgeber, unpublished } \\
\text { data }\end{array}$ \\
Q. ilex & 130 & 330 & N. Martin-StPaul, unpublished data \\
\hline
\end{tabular}




\section{Supplement 7. Physiology-based index of stress water intensity}

The CASTANEA model simulates daily the soil water balance, based on a bucket soil submodel with 2 layers (a top soil layer and a total soil layer, including top soil layer) (Dufrêne et al., 2005). Based on the soil water balance, an index of water stress (reduc, unitless) is calculated daily.

$r e d u c_{t}=\max \left(0, \min \left(1, \frac{S W C_{t}-S W C_{\text {wilt }}}{0.4 \times\left(S W C_{f c}-S W C_{\text {wilt }}\right)}\right)\right)$

where $S_{W} C_{t}$ is the soil water content of day $t(\mathrm{~mm}), S W C_{\text {wilt }}$ is the soil water content at wilting point $(\mathrm{mm})$ and $\mathrm{SWC}_{\mathrm{fc}}$ is the soil water content at field capacity $(\mathrm{mm})$.

reduc calculation is based on the water stress effect on stomatal conductance (Granier et al. 1999).

In addition,

reduc $_{t}=1$ if $S W C t o p_{t}>S W C t o p w i l t \quad($ Eq. S7.2)

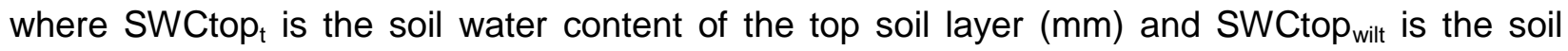
water content of the top soil layer at wilting point $(\mathrm{mm})$. This aims to reproduce the positive effect of light rain (only affecting top soil water balance) on stomatal conductance (Dufrêne et al., 2005).

Finally,

WS_int $=\sum(1-r e d u c t) \quad($ Eq. S7.3)

where WS_int (unitless) is the physiology-based soil water stress intensity index. In the present study, AWBI has been related to the soil water intensity index summed over the growing period $\left(W S \_i n t(n)\right)$ and to the to the soil water intensity index summed over the previous year (WS_int(n-1)). 


\section{Supplement 8. Modelling of the biomass growth onset}

The growth resumption of $F$. sylvatica is known to occur simultaneously with budburst (Michelot et al. 2012) and we simulated consequently the day of growth biomass onset for this species based on the leaf phenology sub-model of CASTANEA (Dufrêne et al. 2005).

For the other species, the day of growth cambial onset was simulated annually using a simple model based on daily temperature and thermic threshold (Rossi et al. 2008, 2011).

In this model a thermic forcing variable $R_{f}$ is calculated daily as follows.

$R_{f}(N)=\left\{\begin{array}{l}T \text { if } T(N) \geq T_{b} \\ 0 \text { if } T(N)<T_{b}\end{array}\right.$

where $\mathrm{N}$ is the day of the year, $\mathrm{T}$ is the daily average temperature and $T_{b}$ is a threshold parameter.

Then,

$\left\{\begin{array}{c}S_{f}(n)=\sum_{N_{\text {start }}}^{N} R_{f}(n) \quad \text { if } \quad S_{f}(n)<T_{\text {crit }} \\ D_{\text {start }}=N \quad \text { if }\end{array}\right.$

where $S_{f}$ is a sum of temperature, $T_{\text {crit }}$ and $N_{\text {start }}$ are parameters and $D_{\text {start }}$ is the day of growth onset. Species-specific parameterization of the growth biomass onset model can be found in Table S8.1. 
Table S8.1. Parameterization of the biomass growth onset model.

\begin{tabular}{ccccc}
\hline Species & $T_{b}$ & $N_{\text {start }}$ & $T_{\text {crit }}$ & Reference \\
\hline Q. petraea & 1 & 51 & 267 & David (2011) \\
P. abies & -2 & 87 & 403.9 & N. Delpierre, unpublished data \\
Q. ilex & 5 & 1 & 933 & N. Martin-StPaul, unpublished data \\
\hline
\end{tabular}

\section{Supplement 9. Uncertainty of the CASTANEA simulations of carbon fluxes}

The capacity of the CASTANEA model to reproduce annual forest $\mathrm{C}$ balance has been thoroughly evaluated over Europe (Delpierre 2009). We reported in Table S9.1 the speciesspecific root mean square error used in the bootstrapp procedure to account for the simulation uncertainty in linear model tests.

Table S9.1. Root mean square error (RMSE) of the CASTANEA simulations (Delpierre 2009). GPP: gross primary productivity, Ra: autotrophic respiration, NPP: net primary productivity.

\begin{tabular}{llllll}
\hline & & Species & & \\
& F. sylvatica & Q. petraea & P. abies & Q. ilex \\
\hline RMSE & GPP & 78 & 104 & 85 & 88 \\
$\left(\mathbf{g C . m}{ }^{-2}\right)$ & Ra & 96 & 186 & 201 & 131 \\
& NPP & 60 & 140 & 66 & 59 \\
\hline
\end{tabular}


Supplement 10. Seasonal agreement between AWBIs and the components of the forest carbon balance

Figure S10.1 (next two pages). Seasonal agreement between AWBls and the components of the forest carbon balance.

Values are the median of the Pearson coefficients estimated on each plot. Triangle marks the maximum median value. Critical values for each flux (G: gross primary productivity, N: net primary productivity, R: autotrophic respiration) are reported with arrows on the color-bar. Critical values outside the color-bar mean that no values differed from the maximum median correlation. 
F. sylvatica
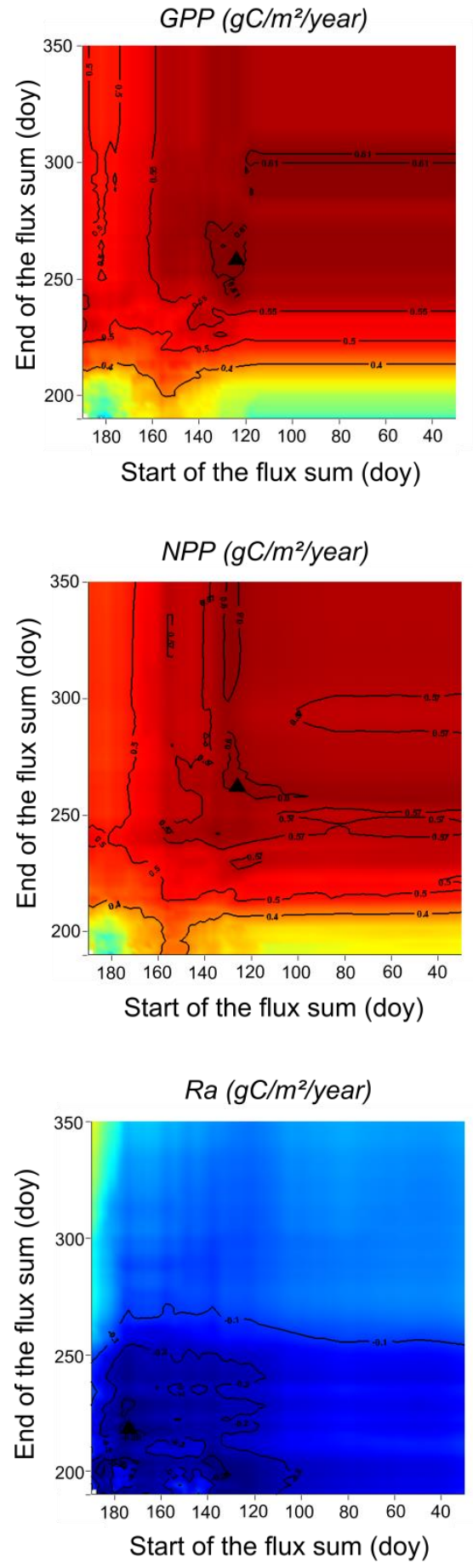

Q. petrea
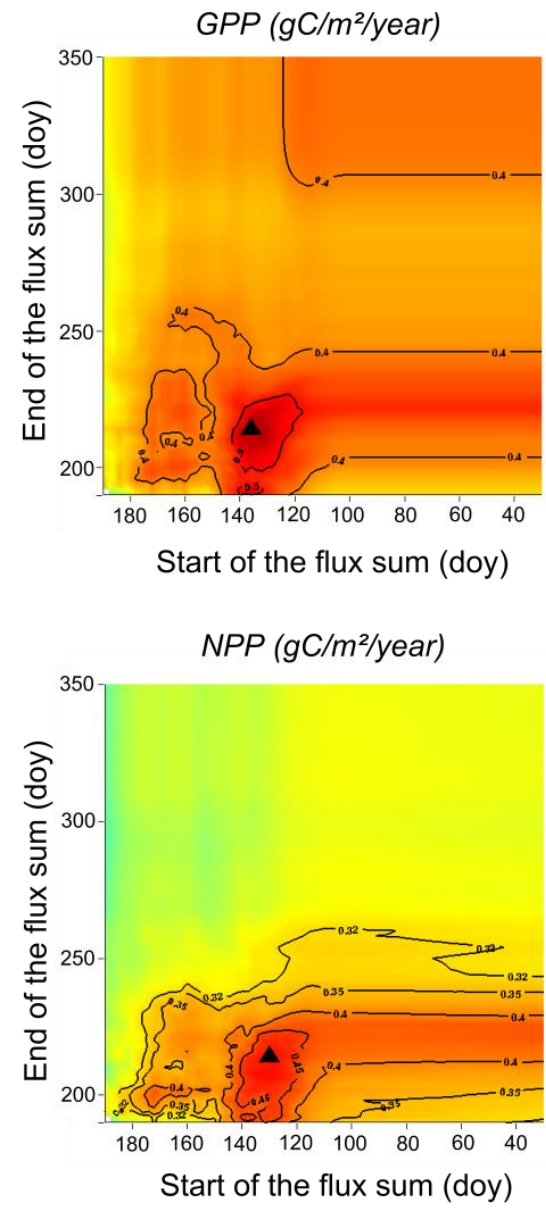

Ra $\left(\mathrm{gC} / \mathrm{m}^{2} /\right.$ year)

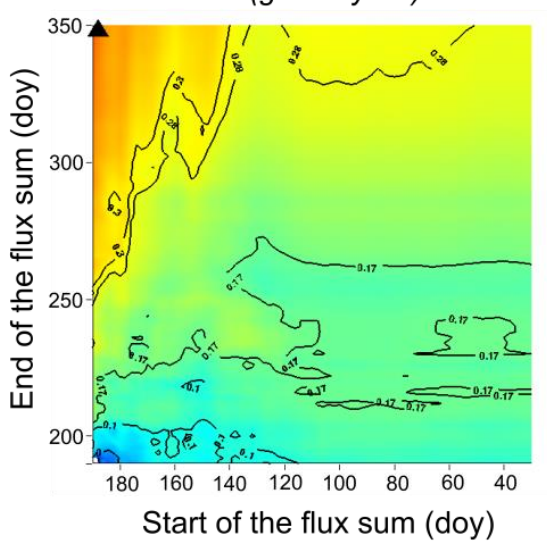

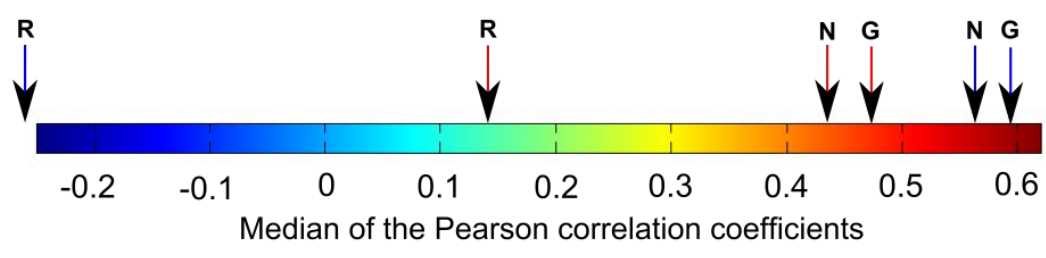

F. sylvatica $\longrightarrow$

Q. petrea $\longrightarrow$ 
P. abies
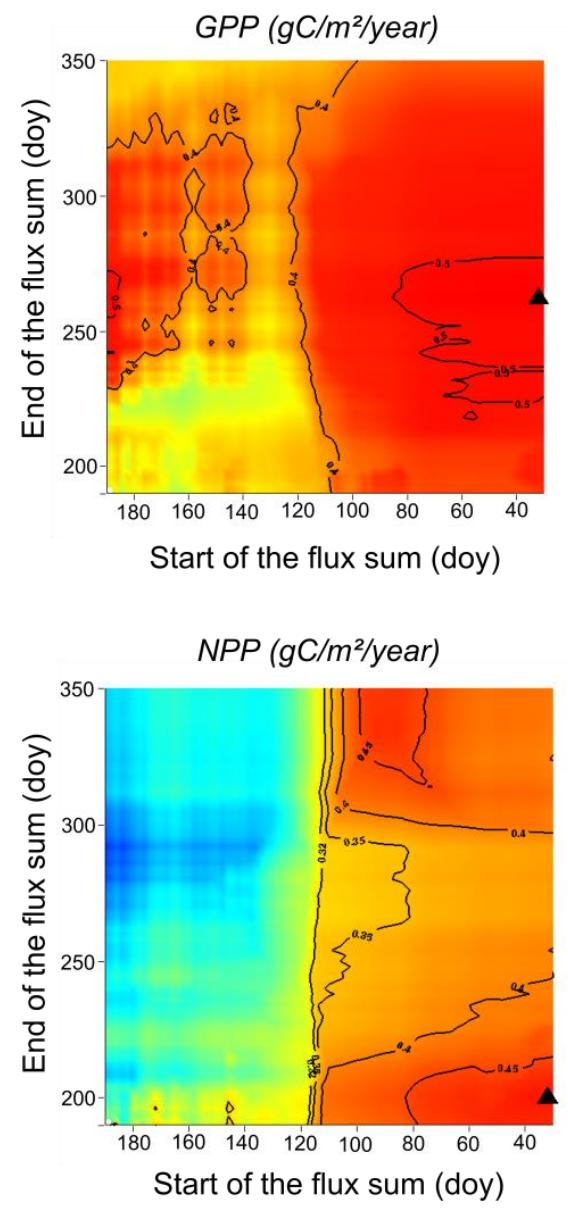

$\mathrm{Ra}\left(\mathrm{gC} / \mathrm{m}^{2} /\right.$ year)
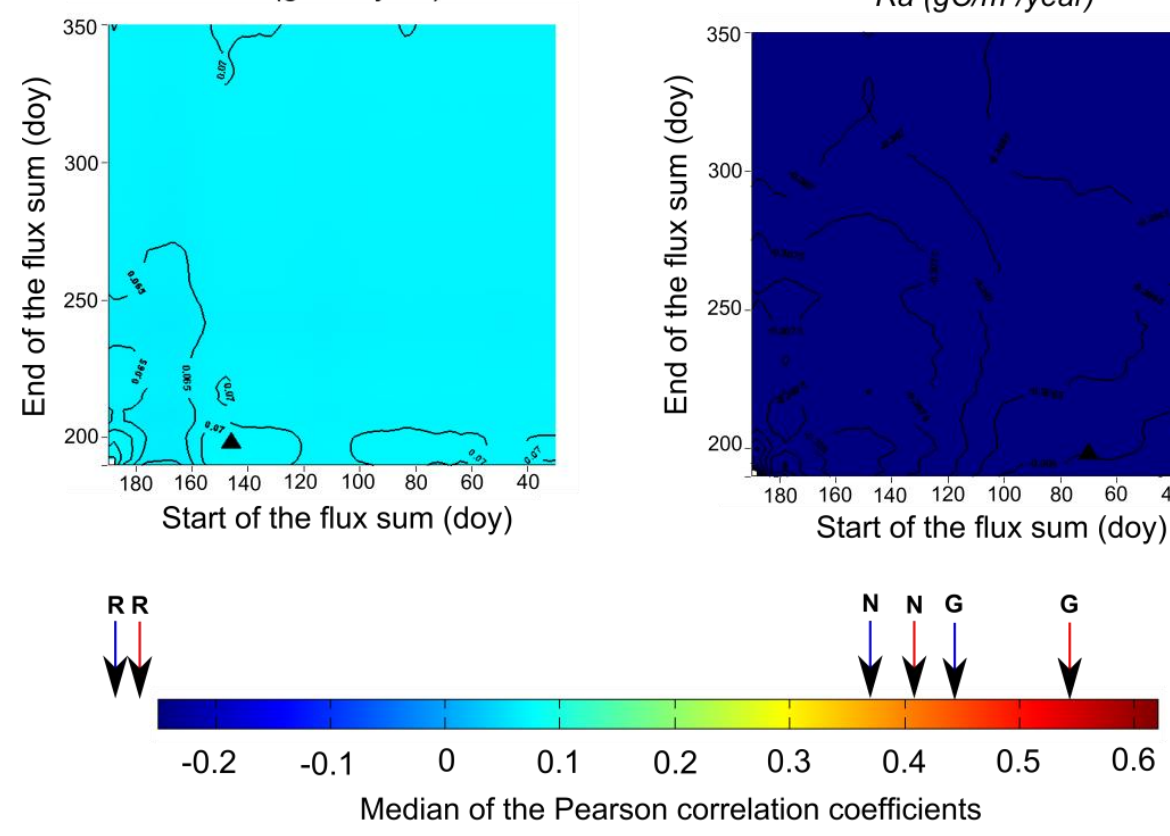

Q. ilex
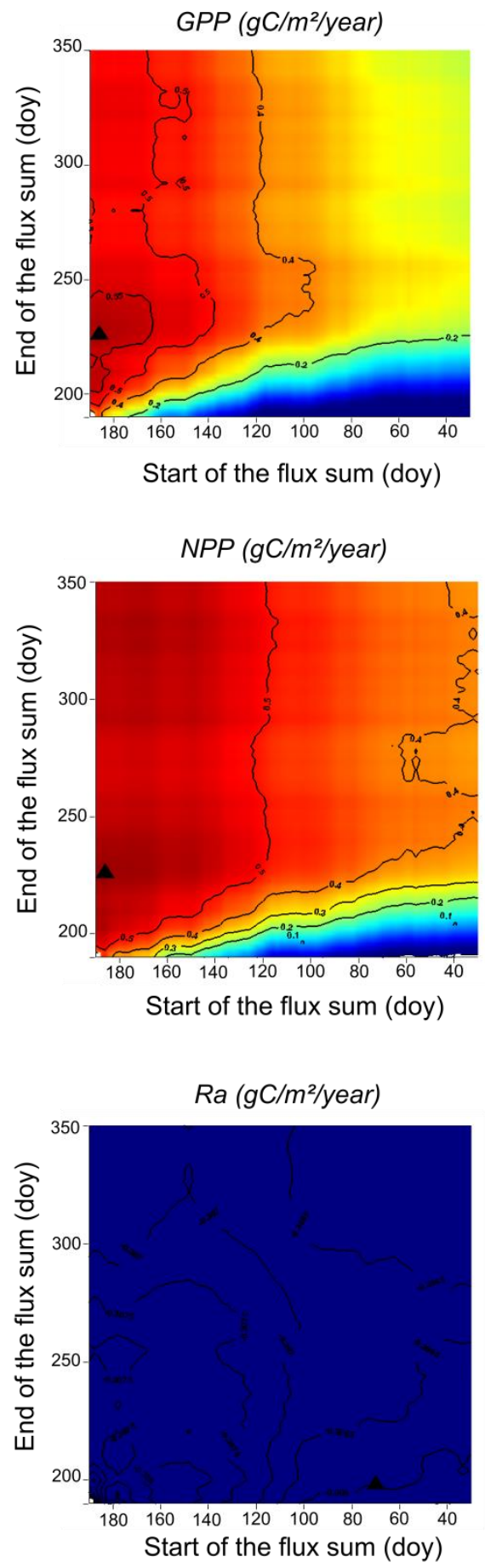

P. abies $\longrightarrow$

Q. ilex $\longrightarrow$ 


\section{References}

Bergès, L., Nepveu, G. \& Franc, A. (2008) Effects of ecological factors on radial growth and wood density components of sessile oak (Quercus petraea Liebl.) in Northern France. Forest Ecology and Management, 255, 567-579.

Bontemps, J.-D., Hervé, J.-C. \& Dhôte, J.-F. (2009) Long-term changes in forest productivity: a consistent assessment in even-aged stands. Forest Science, 55, 549-564.

Bontemps, J.-D., Herve, J.-C., Duplat, P. \& Dhôte, J.-F. (2012) Shifts in the height-related competitiveness of tree species following recent climate warming and implications for tree community composition: the case of common beech and sessile oak as predominant broadleaved species in Europe. Oikos, 121, 1287-1299.

Bouriaud, O., Bréda, N., Le Moguédec, G. \& Nepveu, G. (2004) Modelling variability of wood density in beech as affected by ring age, radial growth and climate. Trees - Structure and Function, 18, 264-276.

David, A. (2011) Modélisation de La Croissance Ligneuse Chez Le Hêtre et Le Chêne Sessile. Master's Thesis Dissertation. Université Paris-Sud, Orsay.

Deleuze, C., Pain, O., Dhôte, J.F. \& Hervé, J.C. (2004) A flexible radial increment model for individual trees in pure even-aged stands. Annals of Forest Science, 61, 327-335.

Delpierre, N. (2009) Etude Du Déterminisme Des Variations Interannuelles Des Échanges Carbonés Entre Les Écosystèmes Forestiers Européens et L'atmosphère: Une Approche Basée Sur La Modélisation Des Processus. Université Paris-Sud.

Dhôte, J.-F. \& Hercé, É. de. (1994) Un modèle hyperbolique pour l'ajustement de faisceaux de courbes hauteur-diamètre. Canadian Journal of Forest Research, 24, 1782-1790.

Dufrêne, E., Davi, H., Francois, C., Le Maire, G., Le Dantec, V. \& Granier, A. (2005) Modelling carbon and water cycles in a Beech forest. Part I: Model description and uncertainty analysis on modelled NEE. Ecological Modelling, 185, 407-436.

Fritts, H.C. (2012) Tree Rings and Climate. Elsevier.

Genet, H., Bréda, N. \& Dufrêne, E. (2010) Age-related variation in carbon allocation at tree and stand scales in beech (Fagus sylvatica L.) and sessile oak (Quercus petraea (Matt.) Liebl.) using a chronosequence approach. Tree physiology, 30, 177-92.

Granier, A., Bréda, N., Biron, P. \& Villette, S. (1999) A lumped water balance model to evaluate duration and intensity of drought constraints in forest stands. Ecological Modelling, 116, 269-283.

Guillemot, J., Delpierre, N., Vallet, P., François, C., Martin-StPaul, N.K., Soudani, K., Nicolas, M., Badeau, V. \& Dufrêne, E. (2014) Assessing the effects of management on forest growth 
across France: insights from a new functional-structural model. Annals of Botany, 114, 779-793.

Guilley, E., Hervé, J.-C. \& Nepveu, G. (2004) The influence of site quality, silviculture and region on wood density mixed model in Quercus petraea Liebl. Forest Ecology and Management, 189, 111-121.

Lebourgeois, F. (1997) RENECOFOR - Etude dendrochronologique des 102 peuplements du réseau. Office national des forêts, Département des recherches techniques.

Lehtonen, a, Mäkipää, R., Heikkinen, J., Sievänen, R. \& Liski, J. (2004) Biomass expansion factors (BEFs) for Scots pine, Norway spruce and birch according to stand age for boreal forests. Forest Ecology and Management, 188, 211-224.

Michelot, A., Simard, S., Rathgeber, C., Dufrêne, E. \& Damesin, C. (2012) Comparing the intraannual wood formation of three European species (Fagus sylvatica, Quercus petraea and Pinus sylvestris) as related to leaf phenology and non-structural carbohydrate dynamics. Tree physiology, 32, 1033-45.

Pignard, G., Dupouey, J., Arrouays, D. \& Loustau, D. (2000) Carbon stocks estimates for French forests. Biotechnol. Agron. Soc. Environ., 4, 285-289.

Rambal, S., Joffre, R., Ourcival, J.M., Cavender-Bares, J. \& Rocheteau, A. (2004) The growth respiration component in eddy $\mathrm{CO} 2$ flux from a Quercus ilex mediterranean forest. Global Change Biology, 10, 1460-1469.

Rossi, S., Deslauriers, A., Griçar, J., Seo, J., Rathgeber, C.B.K., Anfodillo, T., Morin, H., Levanic, T., Oven, P. \& Jalkanen, R. (2008) Critical temperatures for xylogenesis in conifers of cold climates. Global Ecology and Biogeography, 17, 696-707.

Rossi, S., Morin, H., Deslauriers, A. \& Plourde, P.-Y. (2011) Predicting xylem phenology in black spruce under climate warming. Global change biology, 17, 614-625.

Seynave, I., Gégout, J., Hervé, J., Drapier, J., Bruno, É. \& Dumé, G. (2005) Picea abies site index prediction by environmental factors and understorey vegetation : a two-scale approach based on survey databases. , 1678, 1669-1678.

Skomarkova, M. V., Vaganov, E. a., Mund, M., Knohl, a., Linke, P., Boerner, a. \& Schulze, E.-D. (2006) Inter-annual and seasonal variability of radial growth, wood density and carbon isotope ratios in tree rings of beech (Fagus sylvatica) growing in Germany and Italy. Trees, 20, 571-586.

Vallet, P., Dhôte, J.-F., Moguédec, G. Le, Ravart, M. \& Pignard, G. (2006) Development of total aboveground volume equations for seven important forest tree species in France. Forest Ecology and Management, 229, 98-110.

Wilhelmsson, L., Arlinger, J., Spångberg, K., Lundqvist, S.-O., Grahn, T., Hedenberg, Ö. \& Olsson, L. (2002) Models for Predicting Wood Properties in Stems of Picea abies and Pinus sylvestris in Sweden. Scandinavian Journal of Forest Research, 17, 330-350. 
Zhang, S.-Y., Owoundi, R.E., Nepveu, G., Mothe, F. \& Dhôte, J.-F. (1993) Modelling wood density in European oak (Quercuspetraea and Quercusrobur) and simulating the silvicultural influence. Canadian Journal of Forest Research, 23, 2587-2593. 